\begin{tabular}{|c|c|}
\hline AUTHORS & $\begin{array}{l}\text { Syden Mishi (Dttps://orcid.org/0000-0002-7727-8946 } \\
\text { Sibanisezwe Alwyn Khumalo (D) https://orcid.org/0000-0002-4330-9249 }\end{array}$ \\
\hline ARTICLE INFO & $\begin{array}{l}\text { Syden Mishi and Sibanisezwe Alwyn Khumalo (2019). Bank stability in South } \\
\text { Africa: what matters?. Banks and Bank Systems, 14(1), 122-136. } \\
\text { doi:10.21511/bbs.14(1).2019.11 }\end{array}$ \\
\hline DOI & http://dx.doi.org/10.21511/bbs.14(1).2019.11 \\
\hline RELEASED ON & Wednesday, 27 February 2019 \\
\hline RECEIVED ON & Monday, 02 July 2018 \\
\hline ACCEPTED ON & Monday, 21 January 2019 \\
\hline LICENSE & $\begin{array}{l}(\mathrm{cc}) \mathrm{EY} \\
\text { This work is licensed under a Creative Commons Attribution } 4.0 \text { International } \\
\text { License }\end{array}$ \\
\hline JOURNAL & "Banks and Bank Systems" \\
\hline ISSN PRINT & $1816-7403$ \\
\hline ISSN ONLINE & $1991-7074$ \\
\hline PUBLISHER & LLC "Consulting Publishing Company "Business Perspectives" \\
\hline FOUNDER & LLC "Consulting Publishing Company "Business Perspectives" \\
\hline$\sigma^{0}$ & ニニ: \\
\hline NUMBER OF REFERENCES & NUMBER OF FIGURES \\
\hline 75 & 3 \\
\hline
\end{tabular}

(c) The author(s) 2022. This publication is an open access article. 


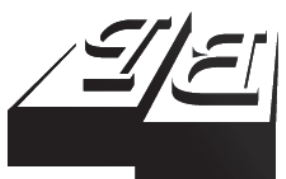

BUSINESS PERSPECTIVES

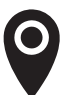

LLC "CPC "Business Perspectives" Hryhorii Skovoroda lane, 10, Sumy, 40022, Ukraine

www.businessperspectives.org

Received on: $2^{\text {nd }}$ of July, 2018 Accepted on: $21^{\text {st }}$ of January, 2019

(C) Syden Mishi, Sibanisezwe Alwyn Khumalo, 2019

Syden Mishi, Doctor of Commerce, Economics, Senior Researcher, Department of Economics and Govan Mbeki Research \& Development Centre, University of Fort Hare, East London, South Africa.

Sibanisezwe Alwyn Khumalo, Doctor of Commerce, Economics, Senior Lecturer, Department of Economics and Economic History, Rhodes University, South Africa.

\section{BANK STABILITY IN SOUTH AFRICA: WHAT MATTERS?}

\begin{abstract}
The study examined the determinants of bank stability within the South African banking sector. By controlling for individual bank characteristics and market characteristics, the study determined possible determinants of solvency, a proxy for bank stability, measured by z-score within the South African financial sector. The South African financial sector is highly concentrated but with a significantly large number of banks, the greater portion being foreign owned banks. The business models of some of the financial intermediaries differ from the big four and therefore the influence of the type of business model is of great interest in this study, as it highlights a unique feature of the South African financial sector. The study's investigation used panel data estimation techniques and found that among the specific bank characteristics, lending activity and capitalization do significantly affect solvency of banks and at sector level concentration was significant. The crisis dummy also revealed that the presence of a financial crisis heightened insolvency. The results have implications for financial institutions and therefore are of interest to regulators, bank management and researchers. Policy prescription in the form of Prompt Corrective Action framework is made to ensure proactive reaction to trends likely to cause instability.
\end{abstract}

\section{Keywords}

bank solvency, bank concentration, z-score, financial crisis, bank regulation, bank lending, diversification, bank funding

JEL Classification G21, G33, G32, D43, D22

\section{INTRODUCTION}

Banking sector is arguably the most fragile and contagious (Denis \& Negotei, 2018; Fouejieu 2017; Giavazzi \& Giovannini, 2010), in that regard making it one which is closely guarded by authorities to ensure stability (Blanchard, Dell'Ariccia, \& Mauro, 2010). Overall system stability is the main focus for macro-prudential policies and allows for significant revisions when the objective is not achieved or where there are signs of deviation from stability (Gersl \& Hermanek, 2006; Alshubiri, 2017). Similarly, it has also been the focus of past research but problems arise as a result of aggregation techniques (Denis \& Negotei, 2018; Fouejieu, 2017). The implication is that: individual banks are all stable, or does each individual bank stability guarantee overall system stability. Financial stability's building block starts at individual bank level, this study's focus, with the hope to conduct system wide analysis at a later stage for brevity and ensuring exhaustive analysis at each stage.

South Africa has undergone changes and adjustments in relation to its regulatory framework. These revisions include twin-peak regulation, in line with changing times, innovation and sophistication of the entities and lessons learnt from past crises like the Global Financial Crisis of 2008-2009 (National Treasury, 2018). A move to macro prudential regulation enables greater disclosure requirements under Basel Accord. The changes have been registered in many countries, both developed and developing, and South Africa is not an exception (Ichiue 
\& Lambert, 2016). South Africa is an interesting case study to explore for two reasons: its persistent observation of Basel Accord recommendations, hence viewed as being well regulated, has adopted macro-prudential regulatory framework from year 2013 with twin-peak regulation completely introduced in 2018. Twin-peak regulation is very pertinent to this as a bank operates under two regulators to meet their needs and demands. Second, it makes use of inflation targeting framework. Recent works (Fouejieu, 2017; Montes \& Peixoto, 2014; Blanchard, Dell'Ariccia, \& Mauro, 2010) point to inflation targeting as a reason for rising financial instability.

Given the present discussion, the aim of the study is to investigate what matters for bank stability, given the significance of stability in overall financial sector health and performance. It is more compelling to investigate this matter in a South African context considering the background given.

Investigating the determinants of solvency among banks is of interest to both academics and practitioners as it is central to the well-being of the financial sector, which is an engine of economic growth. Arguably, ensuring stability within the banking system relates directly to protecting economic agents and the economy in general. Berger, Klapper, and Turk-Ariss (2008) point out that the financial system is a channel that can transmit any instability that emanates from the banking sector into the other sectors of the economy. The result of this is a shock to the lending and credit market. The shock has a disruptive impact on the economy, hence the behavior of banks and characteristics of the banking sector could provide factors that indicate or are strongly correlated with the level of solvency and ultimately the stability of banks. The behavior of banks and the characteristics of the banking sector could be influenced by shocks such as a crisis.

A case in point is the global financial crisis that erupted in the 2007, which saw the interest rate levels being at their lowest globally and not only in South Africa, when considering protracted periods of time (SARB, 2013). This raises the question: Can banks be induced into taking on riskier activities to maintain their profitability and to what extent could that risk taking behavior be stretched to before threatening the stability of financial institutions operating within the South African economy? Recent literature has focused mainly on developed countries (see, for example, Ayadi, Naceur, Casu, \& Quinn, 2016) or cross country studies (see Bitar, Naceur, Ayadi, \& Walker, 2017).

Bank solvency within the South African sector is sparsely investigated, this is despite the sectors' unique characteristics. According to BASA (2014), the sector is highly concentrated with four largest banks controlling over $84 \%$ of the sector assets; predominantly unsecured lenders competing with conventional commercial banks and the financial system is well regulated and highly sophisticated at global standards. Studies have looked at the role of competition on financial stability (Carletti \& Hartmann, 2003; Hellman, Murdock, \& Stiglitz, 2000; Jimenez, Boyd, \& De Nicolo, 2005; Lopez \& Saurina, 2007) and found that increased competition increased the moral hazard behavior of both banks and clients. The likely effect of this behavior is closely associated with increased bank instability. Literature (Berger, Demirguc-Kunt, Levine, \& Haubrich, 2004; Boyd, De Nicolo, \& Jalal, 2006; Schaeck, Cihak, \& Wolfe, 2006; Beck, Demirguc-Kunt, \& Levine, 2006) has also paid considerable attention to the role of the characteristics of the banking sector with an emphasis on concentration. The inconclusive views stem from findings that less concentration lowers likelihood of bank failure, while the ambiguity of the measures of concentration leads to inconsistent results.

The study aims to add value to existing literature by determining factors affecting stability of South African financial institutions. By being able to identify the activities that drive insolvency, among South African banks, policy makers and regulators can be able to craft relevant and effective measures to help strengthen the stability of the financial sector. South African financial sector is to be regulated under the twin-peak paradigm, which entails the setting up of a prudential authority and market conduct authority (Havenmann \& Gibson, 2014). It is imperative for both sets of authorities that existing banks re- 
main solvent and any new entrants find it possible to remain viable. The motivation is to ensure stability within the financial system, and it is equally important to understand what activities matter for bank stability and is the crux of inquiry in this study.

South African banking sector is an interesting case study ${ }^{1}$ given the banking crisis it has experienced, and how it withered the global financial crisis, as well as the high concentration level. The rest of the paper is organized as follows. Section one provides a brief overview of the SA banking sector, while the second section reviews available literature. Section third presents and discusses methodology, while section four discusses empirical findings. Section five also presents discussion and the last section concludes.

\section{THE SOUTH AFRICAN BANKING SECTOR}

The importance of the financial sector in the economy in relation to the development of the economy needs no emphasis and its stability thereof (see, for example, Cihak et al., 2012; Demirguç-Kunt \& Levine, 2008; and Beck et al., 2007). The analysis will provide an output that can be used for comparisons with other emerging and developing economies. This is of great assistance in the drive to help keep stability and maintain depositor confidence thus limiting the occurrence of bank runs and any possible financial crisis that may result thereafter, within emerging economies and developing economies. South Africa once experienced a domestic financial crisis in 2001-2002 which, within a space of three months, saw the country's sixth, seventh and eighth largest banks (BoE, Saambou, Unifer) exiting the market (Theobald, 2013). During this shock, Theobald (2013) further notes that the government through its various institutions issued open ended guarantee on some of the banks that were nursing contagion effects (e.g., BoE, also African Bank, Investec and Nedbank felt the heat) to no avail. This exit occurred despite the fact that such guarantees meant these were supposed to be the safest banks in the economy. It is therefore imperative to understand what counts in relation to bank stability as past experience highlights the difficulty it has proved to be curtailing contagion. The risk of insolvency in the above cases though not systematic has long lasting effects just as systematic bank runs that can cripple the entire financial sector. Confidence within the financial sector is always damaged. Caprio and Klingebiel

Source: BASA (2014).

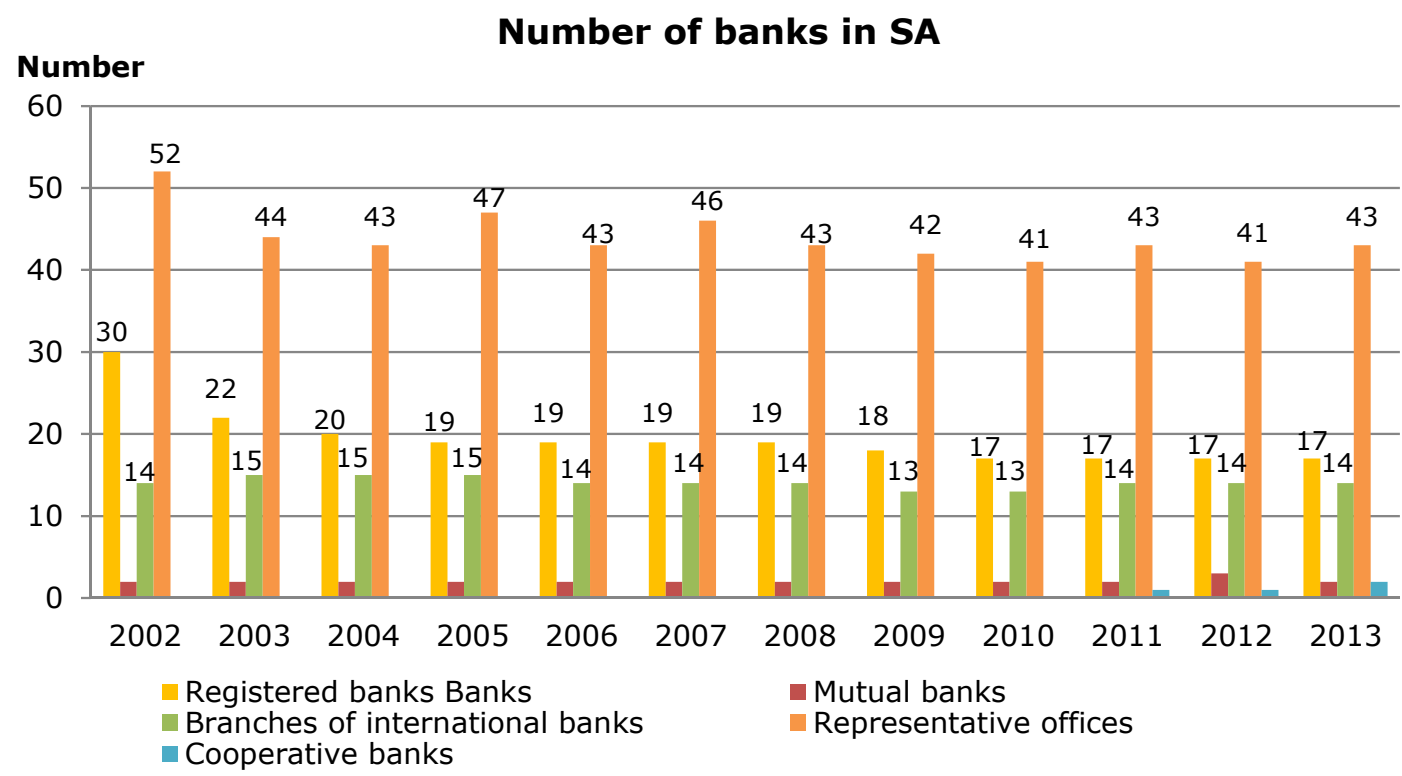

Figure 1. Number of banks in South Africa, 2002-2013

1 South Africa is ranked 3rd in Financial Sector Development, out of 148 countries, BASA (2013). 
(1996) note that a major case of a systematic risk in South Africa was experienced in 1997.

The South African banking sector compares favorably well with those of industrialized countries due to sound regulations and sophistication. Banking Association South Africa (BASA) (2013) reports on the various changes the sector has undergone, especially during the new democratic dispensation, post 1994 . The sector has 17 registered banks, of which three are mutual banks, one construction bank and one development Finance Corporation, 14 local branches of foreign banks and 43 representative offices (BASA, 2014).

Despite the seemingly large number of banks, only four dominate the market, known as "the big four" (Standard Bank, ABSA, FirstRand, and Nedbank) accounting for over 84 percent of total banking assets $(26,22,19$ and 18 percent, respectively) (BASA, 2013). Irrespective of this structure of the South African banking sector, Mlambo and Ncube (2011) assert that the sector dominates the African landscape. Across Africa, outside South Africa, by 2008, South African banks represented 40.4 percent of the total banking assets, 34.6 per cent of net earnings, 49.9 per cent of bank credits, and 42.4 per cent of bank deposits. Maredza and Ikhide (2013) report an 8.9\% increase in banking sector assets between 2010 and 2011 (R 3,406 billion). The domestic market is growing and makes up a significant portion of the African market.

\section{LITERATURE REVIEW}

In the context of high concentration within the South African market, the franchise value paradigm and concentration-fragility/stability nexus can adequately guide this study (Dexu, 2016; Zhao, 2017). However, it is prudent to acknowledge relationship between banking sector concentration, competition and stability as not straightforward (Carletti \& Hartmann, 2003).

The "franchise value" paradigm posits that banks are constrained from risk-taking behavior as the costs for such activities rise with the value of the entity over and above its tangible assets (Zhao, 2017; Keeley, 1990). High competition would eat into profits, and thus franchise value. This would then likely lead to greater risk appetite of banks and most likely greater financial instability (Jimenez, Lopez, \& Saurina, 2013). This theory singles out the significance of competition/concentration within the banking sector and its effect on the sector's stability. On the other hand, in the context of franchise value paradigm, Zhao (2017) in the case of China concluded that before the implementation of the explicit deposit insurance system, the self-discipline effect of the franchise value is completely ineffective in the context of the government-guaranteed implicit deposit insurance system.

In literature, a number of studies tested two hypotheses: concentration-stability and the concentration-fragility hypotheses. The first hypothesis is underpinned by the argument that bigger banks in highly concentrated markets may charge higher interest rate as they control the market, yielding higher profits. Such high profits have a positive marginal effect acting as buffer against loan losses thereby increasing the franchise value and reducing risk appetite of the individual bank (see for example, Marcus 1984; Demsetz, Saidenberg, \& Strahan, 1996). This translates to a stable financial sector with cheaper monitoring and supervision costs as only a few large banks hold diversified and complex portfolios. On the contrary, concentration-fragility hypothesis argues that bank fragility is common with highly concentrated market. OECD (2011) cited banking systems of Switzerland and the Netherlands as good examples to prove this hypothesis. Bigger banks charge higher interest rates that will most likely to increase the probability of clients defaulting, creating a conducive environment for the moral hazard problem and thus higher default risk. When the two hypotheses are combined, Martinez-Miera and Repullo (2010) found the relationship between competition/concentration and bank stability (fragility) being $U$-shaped. This implies that the outcome on whether competition results in bank stability or fragility depends on the nature of the market-stability view that dominates monopolistic markets, while fragility view is prevalent in competitive markets.

Paligorova and Jimenez (2012) focused on risk taking as a possible transmission channel. They highlight that the risk taking behavior of financial 
institutions affects the supply of credit within the economy. Prolonged low levels of interest rates in an economy can increase the risk taking behavior of financial institutions by extending credit to risky borrowers, as also highlighted by Rajan (2006) and Boivin (2011). From a different angle, Paligorova and Jimenez (2012) note the increase in collateralized borrowing by financial institution is an indication of increased risk taking, a view supported by Adrin and Shin (2010). In addition, Yüksel (2017), for the case of Turkey (an emerging economy as South Africa), found out that decrease in industry production index is the most important determinant of the increase in credit risk, with proxy as non-performing loans. In this regard, the overall performance of the economy has a bearing on risk profile of individual banks. Similarly, Yüksel (2017) analyzed panel data for banks in a single country, Turkey.

On the other hand, diversification has been traditionally seen as advantageous in terms of risk reduction. However, Wagner $(2006,2010)$ shows that it is only possible at individual bank level theoretically; for the whole financial system it is to the contrary. This is because diversification later converges and produces banks more similar, increasing the likelihood of systemic crisis. Diversification is often observed under conditions favoring the increase in non-interest income, which is noted by Yüksel, Mukhtarov, Mammadov, and Özsarı (2018), as non-interest income of the banks increases, for example credit card fees and commission, financial performance of the banks improves thus resulting in higher bank profitability. Imperative to note, however, that seeking more non-interest income can expose the bank to more risk as the resources are thinly spread to manage the portfolio of assets. As argued above, diversification is more beneficial to the whole system and much more to the individual bank if it entails unique products which gives competitive advantage. It is significant to highlight observations by Fiordelisi and Salvatore (2013) that profit maximization also has a significant impact on the probability of banks survival and further to financial stability.

Literature highlights that banking crises are mostly a result of factors associated with the asset side of the balance sheet of the financial institutions, although the factors affecting the liabilities side technically are expected to also result in a banking crisis. Kibritcioglu (2002) notes that deposit runs, which affect the liabilities of the financial institution, weaken the banking system and increase chances of insolvency. Reinhardt (1999) further notes that the weakening of the banking sector leads to excessive risk taking leading to an increase in the non-performing loans, that is to say an increase in credit risk and higher chances of insolvency. This is supported by Freixas et al. (2000), and Allen and Gale (2000) stating that higher capitalization curtails possible contagion effects from individual bank failures in the same economy. Regarding bank stability for Central and Eastern Europe, Miklaszewska, Mikołajczyk, and Pawlowska (2012) applied the same method. This resulted in observing a sharp decline in bank stability during the financial crisis. In addition, Ozili (2018) observed that the effects of financial structure, institutional and bank-level factors on financial stability of individual banks vary with the different stages of financial crises, with results different before, during and post global financial crisis in the case of Africa.

Caprio and Klingebiel (1996) in their study classified possible determinants of bank insolvency into two groups. They noted that bank solvency is subject to macro- and microeconomic factors. Their study found a decrease in terms of trade and recession where macroeconomic factors have the largest impact on bank solvency, while poor bank management and poor regulation are the leading causes of bank insolvency amongst microeconomic factors. The argument regarding macroeconomic factors resonates with the findings of Yüksel (2017) discussed above, while the one on management and governance as well as regulations is discussed in Chitan (2012) for the case of Romania and in the case of Turkey by Tunay and Yüksel (2017) albeit with a bias towards foreign bank operations. On the other hand, Chen, Jeon, Wang, and $\mathrm{Wu}$ (2015) indicated the significance of corruption in bank risk-taking, arguing that higher levels of corruption increase the risk-taking behavior of banks. Regarding corruption, Barry, Lepetit, and Strobel (2016) observed that when state-owned banks or family-owned banks provide a higher proportion of credit to the economy, corruption is higher. Corruption is, however, not 
straightforward to measure and the focus in this study has been on overall regulations as well as individual bank characteristics which would point to cooperate governance quality.

Tunay and Yüksel (2017) take note that increasing levels of competition in the developing world as foreign banks enter the market will improve the institutional governance of the banking system and the presence of foreign banks in the system causes the local banks to be more cautious about taking risks and this decreases the possibility of fragility and crisis. This is in line with the works by Arun and Turner (2004), Caprio and Levine (2002), Levine (2004).

In a study on Romanian banks, Diaconu and Oanea (2015) found that financial stability among commercial banks is exogenous as no factor was found to influence it (the considered factors were macroeconomic general situation (inflation and GDP growth, financial market situation (BET rate)) and banking sector situation (interbank offering rate for three months - ROBOR $3 \mathrm{M}$ )). However, in the same study, financial stability of co-operative banks was found to be mainly influenced by two factors represented by GDP growth and interbank offering rate for three months. The explanatory variables were mainly macroeconomic and sector specific than individual bank based. This study argues for the controlling of bank based characteristics in line with Ozili (2018) and Danişman (2018).

Adusei and Elliot (2015) in the case of Ghana rural banks questioned whether bank size and funding risk do have an impact on bank stability. They found that an increase in the size of a rural bank results in an increase in its stability, and funding risk positively impacts bank stability. The present study controls for bank size as well as funding structure in line with this study, as we consider these critical characteristics at bank level.

Financial stability is not straightforward to measure, however literature mainly proposes Z-score (Diaconu \& Oanea, 2015; Alshubiri, 2017; Ozili, 2018). According to Čihák (2007), the main advantage of this measure is simplicity of financial calculations, the main disadvantage is represented by the fact that it does not present the correlation between financial institutions. Ozili (2018) made use of four measures of banking stability, namely banks' loan loss coverage ratio, insolvency risk, asset quality ratio, and level of financial development. The argument being that this will allow analysis of banking stability determinants from four complementary perspectives: protection for downside credit losses, distress arising from insolvency risk, non-performing loans, and financial development. The key development from studies like Diaconu and Oanea (2015) is that individual bank factors are included, specifically the model controlled for financial structure, institutional, bank-level factors. Alshubiri (2017) also considered bank specific characteristics such as income diversity and size of a bank, banking sector concentration in the market and $\mathrm{P} / \mathrm{E}$ ratio in the case of Sultanate of Oman.

Having looked at the above factors that emerge from literature, the hypothesis is that bank specific characteristics significantly determine financial stability. With the effect dependent on the nature of the financial system, vis-a-vis, concentration and competition within the sector.

The aim of the paper is to investigate what factors need to be considered in ensuring and maintaining stability at the individual bank and system wide level.

\section{METHODOLOGY}

To identify factors that determine bank insolvency, the following model is proposed, as informed by literature (see, for example, Srairi, 2013).

$P(\pi<-E)_{i t}=B S_{i t}+S_{t}+M_{t}+\varepsilon_{i t}$,

where $P$ indicates probability, $\pi$ is profitability, and $E$ is the equity capital of the entity.

The probability of default is proxied by z-scores. According to equation (1) specification, probability of insolvency is a function of bank specific characteristics, sector specific condition (market concentration) and the macroeconomic indicators. Bank specific characteristics included are: capitalization, lending activity, funding structure, and diversification, while the sector envi- 
ronment is captured by market concentration as measured by HHI. On the other hand, macroeconomic variables controlled include interest rate and business cycles.

\subsection{Dependent variable}

Z-score: It is very popular in literature for capturing probability of insolvency for firms because it is easy to calculate and takes information from accounting data which is readily available. Its origin can be traced to the works of Roy (1952), Blair and Heggestad (1978), and Boyd et al. (1993) and has been used extensively of late in empirical works (Zhang, Xie, Lu, \& Zhang, 2015; Srairi, 2013). The higher the $\mathrm{z}$-score, the lower the probability of insolvency of that particular entity. Although it can be argued that it is more informative to use actual distress events in such study, we use z-score for reasons of comparability with the existing literature and that it can be derived from accounting data that is readily available.

For the purpose of this paper,

$$
z-\text { score }=\frac{R O A+C A R}{\delta(R O A)} .
$$

\subsection{Independent variables}

Capitalization: The ratio of equity to total assets, measuring how well capitalized is the bank (see Kick \& Prieto, 2013). Due to stringent capital requirements (through Basel accords recommendations), South African banks are generally well-capitalized. A well-capitalized bank is expected to have a higher z-score (lower probability of insolvency) than an undercapitalized bank. Therefore, a positive relationship between the two is expected, a priori.

Lending activity: Growth in gross loans was used as a proxy. The expectation is that as a bank lends more (higher growth in gross loans), exposure to default risk becomes high, and therefore a negative relationship is expected between lending activity and $\mathrm{z}$-score (see, for example, Schaeck \& Cihak, 2014).

Funding structure: This variable measures how the bank is funded, considering that banks were traditionally funding their operations through deposit taking and the banks have been "moving to the market" over time. What effect could that move possibly have on risk taking? A ratio of customer deposits to total funding is adopted as a proxy in line with Kick and Prieto (2013).

Diversification: This variable captures how well diversified are the income sources of the bank (Zhang et al., 2015; Schaek \& Cihak, 2014). Traditionally, banks' source of income is derived from extending loans (interest income, of late non-interest income has been increasing). The ratio of non-interest income to gross revenues is the best measure for how diversified the revenues of the bank are. A priori, the effect of diversification on insolvency probability is ambiguous - negative (positive to $\mathrm{z}$-score) if the diversification is into stable streams of revenue and positive (negative to z-score) otherwise.

Market concentration: This is used as proxy for competition within the sector (Kick \& Prieto, 2013). The South African banking sector is well known for its high level of concentration (interpreted as low competition).

Business cycle: There is need to capture the macroeconomic condition (Kick \& Prieto, 2013), and for this study the leading indicator as provided by the central bank is used. The financial crises dummy was also considered to reflect the effects of macroeconomic condition on probability of insolvency.

Interest rate: Captures the policy stance of the central bank. An ambiguous relationship is expected with the z-score.

\subsection{Estimation techniques}

The aim is to look at the key determinants of stability among banks. Therefore, individual specific bank variables were sought and structured into panel series. To allow for clear understanding of the effect across banks, panel estimation techniques were followed given that simple OLS and other time series techniques face serious limitations to handle this kind of data. With the panel data structure, fixed effects of random effects can be assumed. Are variations across banks expected to have a significant effect on the relationship be- 
tween the variables of concern? However, subjective assumptions alone are not sufficient, Hausman tests have been developed to inform selection of the best assumption objectively (Green, 2008). The null hypothesis is that unique errors are not correlated with the regressors. This implies that when the test is significant (at 5\% in this study), fixed effects are assumed.

Graphical display of key variables is further presented.

Figure 2 shows the $\mathrm{z}$-scores for the selected banks in South Africa. According to Figure 2, Nedbank has the highest $\mathrm{z}$-score, therefore it is the most sound of the selected South African banks. Nedbank has consistently had the highest $z$-score for the duration of the period under review. ABSA has increased its $\mathrm{z}$-score over time and currently has the second highest $\mathrm{z}$-score, while Standard Bank has maintained the third position so has Investec. Of note is the rise of FNB's z-score, which indicates a shift in the bank's behavior from being imprudent to prudent, thus a higher $\mathrm{z}$-score.

A look at Figure 2 shows that there are two broad groups, those with high z-scores, which are increasing and those with low z-scores which are on the decline in general. This polarization is a characteristic that is inherent within the South African banking system. Polarization negatively impacts competition within the banking sector as the system is dominated by the leading pack and the tendency is for other banks to take radical actions to try and compete with the leading banks. This is one observation that has led to the constant decline of the other bank's z-score.

Just as was revealed with z-score trends, two distinct groups appear. The big four banks as well as Investec have capitalization ratios moving closely together, characterized by smooth trend as compared to the other four smaller banks. For the top group, the crisis eroded their capitalization, albeit at varying degrees (Figure 3).

Figure 4 shows the levels of growth of the individual bank's loan portfolios. A point to note is the creation of a group consisting of Capitec, Ubank and Bidvest. This group has the highest values for lending activity and also the highest standard deviations. The rest of the selected banks in South Africa are grouped together and tend to move together and have lower values of lending activity coupled with lower standard deviations.

The high standard deviations indicate high instability within the loan portfolios as compared with low standard deviations which indicate stability and consistency within the loan portfolios. From Figure 4 it is evident that stability of the loan portfolios is associated with the banks that are deemed less risky within the South African banking sector thus prudent behavior from these banks. Therefore, the center of discussion in relation to the risk profiles of banks in South Africa is not so much the issue

\section{Z-score}

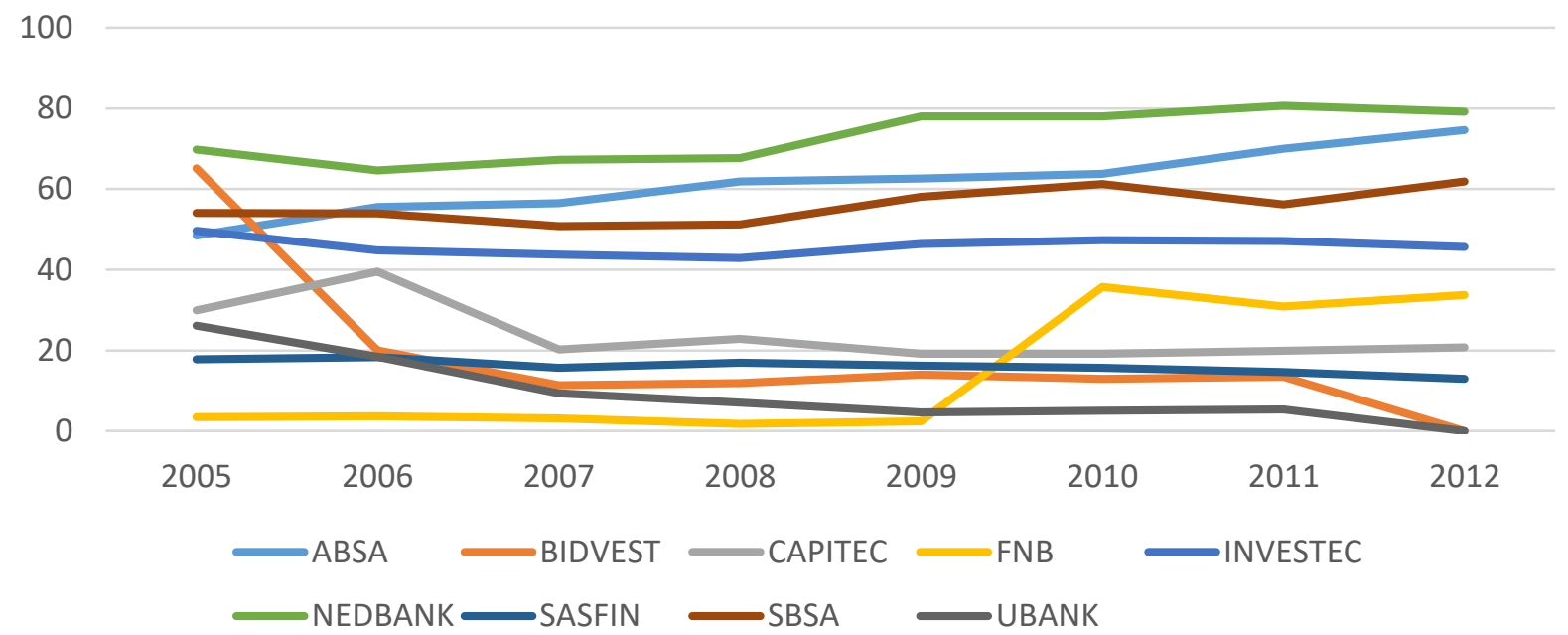

Figure 2. Dependent variable - Z-score 


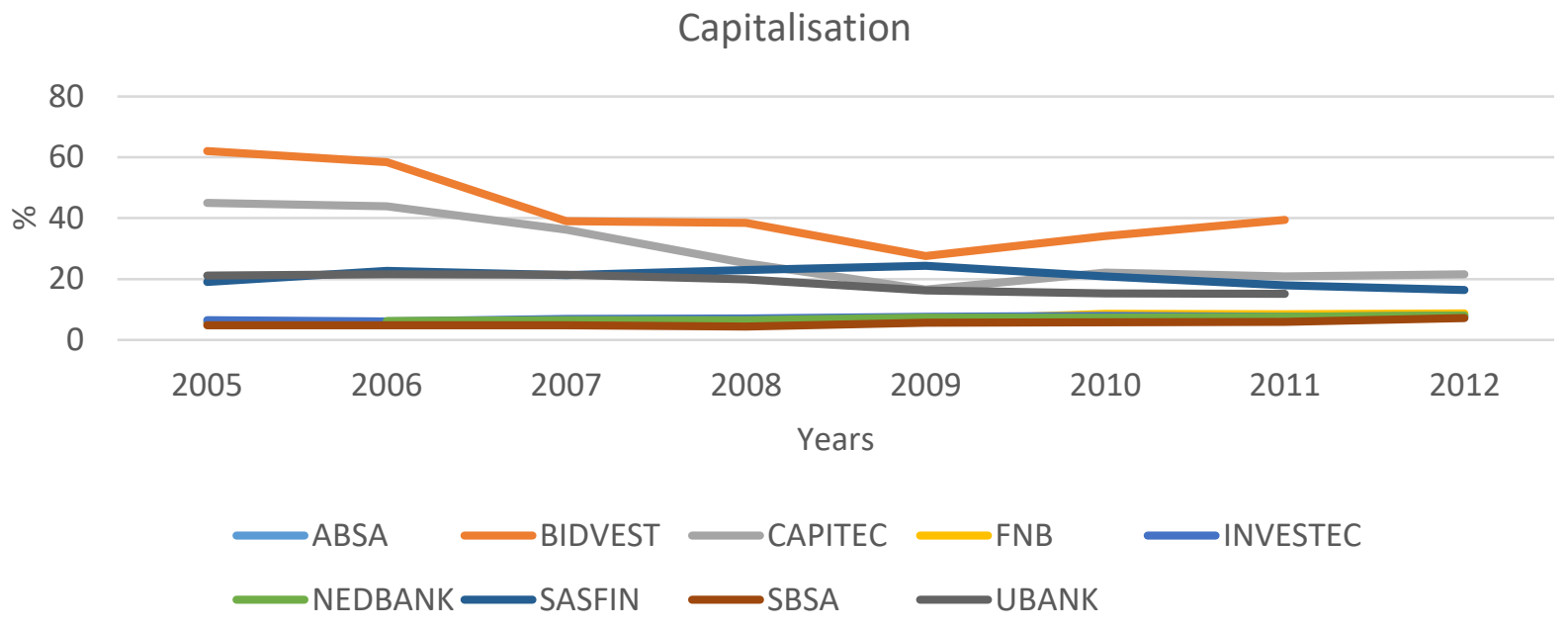

Figure 3. Capitalization (Equity ratio)

\section{Lending Activity}

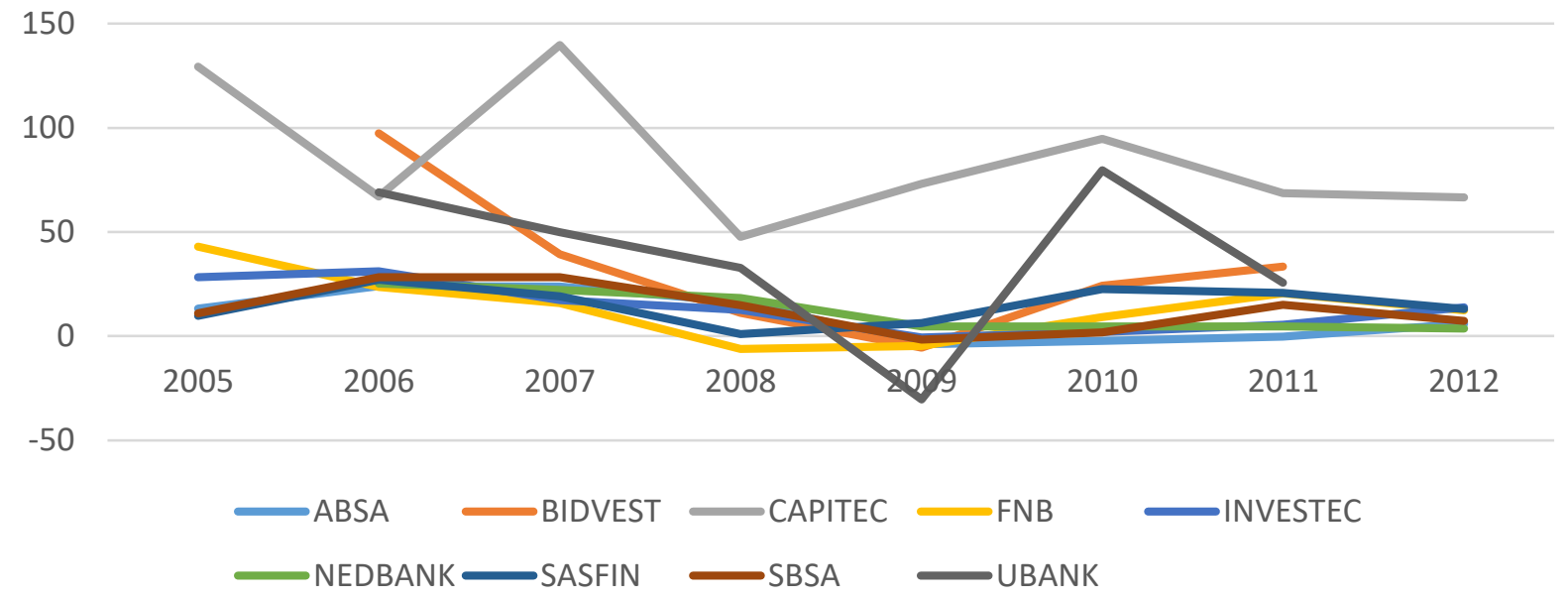

Figure 4. Lending activity

of increases or decreases in lending activity. It is more on the issues pertaining to the level of the lending activity by the banks in relation to the magnitude of these changes over time.

\section{RESULTS PRESENTATION}

The variables were subjected to Augmented DickeyFuller test to identify the order of integration (stationarity level). Results show the variables being integrated of order $1\{\mathrm{I}(1)\}$, except for diversification and sector concentration which are $\mathrm{I}(0)$. For brevity, the full results are not shown here. The next step was to identify the most suitable assumption regarding the relationship between cross sections - random effects versus fixed effects. For that, the data was exposed to Hausman tests and the following results were obtained (see Table 1).

Table 1. Hausman tests - random versus fixed effects assumption

\begin{tabular}{l|c:c:c}
\hline \multicolumn{1}{c}{ Variables } & Fixed & Random & SE \\
\hline $\begin{array}{l}\text { Equity ratio } \\
\text { (Capitalization) }\end{array}$ & 0.75558 & 0.55282 & 0.08965 \\
\hdashline $\begin{array}{l}\text { Lending activity } \\
\text { Funding structure }\end{array}$ & -0.10141 & -0.10024 & -0.00117 \\
\hline Diversification & -0.0105 & 0.02904 & 0.00946 \\
\hdashline $\begin{array}{l}\text { Sector concentration } \\
\text { Financial crisis }\end{array}$ & 1248.362 & 1142.009 & - \\
\hline $\begin{array}{l}\text { fummy } \\
\text { dummon }\end{array}$ & -8.51712 & -8.48955 & - \\
\hline
\end{tabular}

Note: Prob $>$ chi $2=0.4061$. 
From the results in Table 1 , the Prob $>$ chi 2 is greater than 0.05 , therefore random effects were assumed based on this Hausman test.

The selected model was estimated in a generalized least squares framework and the results are presented in Table 2.

Table 2. Presentation of random-effects GLS regression results

\begin{tabular}{l:c:c:c}
\hline $\begin{array}{c}\text { Dependent variable: } \\
\text { Z-score }\end{array}$ & Coef. & $\mathbf{z}$ & $\mathbf{P}>|\mathbf{z}|$ \\
\hline \multicolumn{3}{c}{ Random-effects GLS regression } \\
\hline Equity ratio & 5528156 & 2.42 & 0.016 \\
\hline Lending activity & -1002386 & -2.27 & 0.023 \\
\hline Funding structure & -0290388 & 0.76 & 0.448 \\
\hline Diversification & -.0972271 & -0.83 & 0.407 \\
\hline Sector concentration & 1142.009 & 1.93 & 0.053 \\
\hline Financial crisis dummy & -8.489553 & -3.39 & 0.001 \\
\hline Constant & -180.0933 & -1.61 & 0.106 \\
\hline
\end{tabular}

Note: R-sq: within $=0.3754$, between $=0.2689$, overall $=$ 0.0619 ; Number of obs $=60$; Number of groups $=9$.

Based on the estimated model, the determinants of bank stability have been identified as capitalization, lending activity, sector concentration and financial crisis; funding structure and diversification are not statistically significant. The dependent variable, $\mathrm{z}$-score, is calculated in such a way that those entities with higher score have a lower probability of default, that is, they are stable. From the above results, equity ratio (capitalization) has a positive effect on $\mathrm{z}$-score (stability measure) at $5 \%$ significance level. With the understanding of equity ratio as a proxy for bank capitalization, a unit increase in equity ratio leads to an increase in z-score by 0.55 , which is a movement towards solvency (reducing the probability of default).

The results from Table 2 show that lending activity is significant at $5 \%$. According to the results, lending activity has a negative relationship with the z-score. The indication being that an increase in the lending activity of South African banks has the effect of increasing their exposure to risk, thus a lower z-score. From the HHI measure of concentration, a positive and significant effect of concentration on default probability was found - higher concentration, therefore, leads to lower probability of default (higher $z$-score). According to the results, the stability of banks in South Africa is negatively affected by the presence of a financial crisis. The financial crisis dummy variable is significant at $1 \%$. Under a financial crisis period, South African banks are susceptible to insolvency issues, thus raising their risk profile.

For robustness checks and to ensure sound inferences, the study compared the random effects model chosen by Hausman with its counterpart, the fixed effect as well as the OLS with dummy (LSDV). The results are presented in Table 3. The results of the latter models are mirror images of the former, with differences only on sector concentration which is significant at $5 \%$ in fixed effect and LSDV, compared to $10 \%$ under the random assumption.

Table 3. Comparison of three models

\begin{tabular}{|c|c|c|c|}
\hline & Random & Fixed & $\begin{array}{c}\text { pOOLED } \\
\text { Ols_dum } \\
\text { (LSDV) }\end{array}$ \\
\hline Cap & $0.55282 *$ & $0.75581^{* *}$ & $0.75581^{* *}$ \\
\hline Lending activity & $-0.10024^{*}$ & $-0.10141^{*}$ & $-0.10141^{*}$ \\
\hline Funding structure & 0.02904 & 0.0105 & 0.0105 \\
\hline Diversification & -0.09772 & -0.00375 & -0.00375 \\
\hline $\begin{array}{l}\text { Sector } \\
\text { concentration }\end{array}$ & 1142.0086 & $1248.3618^{*}$ & $1248.3618^{*}$ \\
\hline $\begin{array}{l}\text { Financial crisis } \\
\text { dummy bank }\end{array}$ & $-8.48955^{* * *}$ & $-8.51719^{* *}$ & $-8.51719^{* *}$ \\
\hline 2 & & & $-68.28098^{* * *}$ \\
\hline 3 & & & $-45.4191^{* * *}$ \\
\hline 4 & & & $-48.07954^{* * *}$ \\
\hline 5 & & & $-14.01386^{* * *}$ \\
\hline 6 & & & $12.74414^{* * *}$ \\
\hline 7 & & & $-54.95396 * * *$ \\
\hline 8 & & & -3.20979 \\
\hline 9 & & & $-56.903^{* * *}$ \\
\hline Cons & -180.09325 & -205.62642 & -175.05354 \\
\hline$N$ & 60 & 60 & 60 \\
\hline$R_{2}$ & & 0.385799 & 0.95276 \\
\hline
\end{tabular}

Note: ${ }^{*}-p<0.05 ;{ }^{* *}-p<0.01 ;{ }^{* *}-p<0.001$.

Table 3 results show that the intercept does vary across the banks as the individual bank intercepts for all banks, except bank 8, are statistically significantly different from that of bank one. Overall, bank 6, which is an investment bank, has the highest intercept of -162.3094 , with all others have more negative constants. 


\section{DISCUSSION}

Capitalization-equity ratio: The results are compared with de Bandt (2017), and Miah and Uddin (2017) who also highlight the importance of better quality assets. Imperative to note here that $z$-score increases with the soundness of banks, a positive coefficient indicates a risk-reducing effect. Capitalization as measured by equity ratio has a risk-reducing effect among South African banks. Therefore, it is expected that thinly capitalized banks are expected to take more risk due to higher leverage. The works of Ikpefan (2012) corroborate this finding. In practice we observe that building a capital buffer for banks improves overall performance, thus lowering likelihood of instability (Shaddady \& Moore, 2018; Mirzaei \& Moore, 2014).

Lending activity: This is supported by a study by Reinhardt (1999) who notes that increased credit risk is associated with an increase in non-performing loans that are a result of increased excessive risk. The excessive risk lowers the quality of assets, a direct result of increased lending activity. If this behavior is prolonged, banks' ability to accumulate capital is negatively affected, as was the case in Japan (Acharya, 2018) thus raising the probability of instability. In any case, banks need to lend as their basic business model is generating revenue. Aggressive lending may result in 'reckless lending', a phenomenon that resulted in the creation of National Credit Act (NCA) (2005) in South Africa. NCA restricts unsecured lending, which has potential to expose banks significant to default risk (Goodwin-Groen, 2006; Schraten, 2014).

Concentration: A unique feature of the South African banking sector is its high concentration, which implies low competition. The link between competition and stability has long been established as positive, however recent theoretical literature casts doubt on that prevailing view that lower competition mitigates risk taking incentives, instead positing that higher competition goes along with reduced bank risk (competition-stability versus competition-fragility hypothesis). This implies that as concentration increases (which can be interpreted as lower competition, taking note of limitations detailed in Bikker and Haaf (2002), risk taking behavior of banks declines pre- senting a positive relationship between competition and risk-taking activities. In a highly concentrated sector, industry leaders are well established and therefore incentives to fight for market share decline sharply and in any case the costs related to that could be too much to bear. In that regard, it can be deduced that stability is maintained in a Bertrand model manner, until one firm attempts to cheat (increasing market share at the expense of others), stability breaks down (see the works of Beck, De Jonghe, \& Schepens, 2011; Altunbas, Marques-Ibanez, \& Van Leuvensteijn, 2016; Vives, 2016). This is contrary to the findings and argument that competition has a stability enhancing effect through improving bank efficiency (Schaeck \& Cihak, 2010; Kick \& Prieto, 2013), and precisely by improving banks' monitoring and screening procedures (Shijaku, 2017).

Financial crisis: The financial crisis period is largely linked with low interest rate levels, where the behavior of banks tends to be imprudent, an assertion supported by Paligrova and Jimienez (2012), and Rajan (2006). In the presence of financial crisis, many socio-economic woes creep in, such as loss of employment, loss of business opportunities, decline in production and demand among others, which all increase risk of default and therefore increase instability. In this vein, Shijaku (2017) found competition-stability hypothesis, supporting evidence in the post global financial crisis data in the case of Albanian banking market.

Furthermore, the study used Breusch and Pagan tests post estimation to confirm the assumption of random effects. Based on the results that the Prob $>$ chibar $2=0.000$, we reject the null and conclude that random effects are indeed appropriate. This implies that there are significant differences across banks, and it is not possible to run simple OLS and obtain consistent results. From these results, the South African banking sector fits our a priori expectation that the banks differ according to management philosophy, their business model (for example, predominantly unsecured lenders versus traditional commercial banks and predominantly investment banks, as well as mutual banks) and geographical presence (branch network). All these features are captured by the random term assumed in the model (see Haussmann, 1978; Greene, 2012). 


\section{CONCLUSION}

The paper is set out to investigate what matters to stability among banks in South Africa using panel estimation techniques on a unique data set. The random effects assumption was made based on Hausman tests. The results show positive relationship between capitalization and the stability measure (z-score), while lending activity has a tendency to increase chances of insolvency. Lending activity as measured by the growth in gross loans has an effect of exposing the particular bank to default risk. Other bank specific variables were not significant within the South African context.

On the other hand, lack of competition (high concentration) reduces the chances of insolvency, therefore improves stability. This implies that high concentration (low competition) brings about stability within the banking sector. This may also help explain the resilience that has been displayed by South African banks during the 2007-2009 global financial crisis era despite many financial institutions across the globe having struggled. After all, high concentration is not bad as clear sector leaders are known and smaller banks respect that. However, further research needs to be carried out to investigate the effect of high concentration on costs faced by consumers - stability should not be at the expense of consumers since an oligopoly structure can easily lead to collusion. When financial crisis was considered, it was found out that probability of default increases (reduction in z-score) increasing the risk of insolvency.

Lastly, the South African banking sector is divided into two groups in terms of the key bank specific characteristics, which is mainly along the business model (traditional commercial ones tend to move together over time with great stability in the specific characteristics).

From the findings, the following policy prescriptions are considered, the quality of bank assets is a vital component which the regulatory authorities need to monitor. Prolonged low interest rate environments could lead to evergreen lending as low cost borrowing could grow the lending behavior of banks. Acharya (2018) points to a Prompt Corrective Action framework, which can be implemented in the case of South Africa - this is a law levying progressive penalties against banks that exhibit progressively deteriorating capital ratios. A close monitoring of capital ratios per reporting period is done and any deviations for subsequent periods are penalized. A number of characteristics at bank level can be added to the tracked indicators for the purposes of this policy.

\section{ACKNOWLEDGEMENTS}

Funding from NRF: S\&F Innovation Doctoral Scholarship (GRANT UID: 89077) is greatly acknowledged. The authors are grateful to the Africa Growth 2014 Development Finance Conference - Dubai, participants and the anonymous reviewers for insightful comments. Standard disclaimer applies.

\section{REFERENCES}

1. Acharya, V. V. (2018). Prompt Corrective Action: An Essential Element of Financial Stability Framework. Indian Institute of Technology Conference. Retrieved from https://www.bis.org/review/ r181012k.pdf

2. Adrian, T., \& Shin, H. (2010). The changing Nature of Financial intermediaries and the financial crisis of 2007-2009 (Federal
Reserve Bank of New York Staff Reports No. 439). Annual Review of Economics, 2, 603-618. https:// doi.org/10.1146/annurev.economics.102308.124420

3. Adusei, M. (2015). The impact of bank size and funding risk on bank stability. Cogent Economics \& Finance, 3(1), 1-19. https:// doi.org/10.1080/23322039.2015 .1111489
4. Alshubiri, F. N. (2017). Determinants of financial stability: an empirical study of commercial banks listed in Muscat Security Market. Journal of Business and Retail Management Research, 11(4), 192-200. Retrieved from http://www.jbrmr.com/ cdn/article_file/content _74048_17-07-22-09-56-22.pdf 
5. Altunbas, Y., Marques-Ibanez, D., \& Van Leuvensteijn, M. (2014). Competition and bank risk: The effect of securitization and bank capital (Working Paper Series No. 1678). European Central Bank. Retrieved from https://www. ecb.europa.eu/pub/pdf/scpwps/ ecbwp1678.pdf

6. Amato, J. D., \& Shin, H. S. (2003). Public and private information in monetary policy models (Bis Working Papers No. 138). Retrieved from http://www.nuff. ox.ac.uk/users/shin/pdf/marcon22.pdf

7. Arun, T. G., \& Turner, J. D. (2004). Corporate governance of banks in developing economies: Concepts and issues. Corporate Governance, 12(3), 371-377. https://doi.org/10.1111/j.14678683.2004.00378.x

8. Ayadi, R. B., Naceur, C., Casu, B., \& Quinn, B. (2016). Does Basel Compliance matter for bank performance? Journal of Financial Stability, 23, 15-32. https://doi. org/10.1016/j.jfs.2015.12.007

9. The Banking Association of South Africa (BASA). (2013). The South African Banking Sector. Retrieved from http://www.banking.org.za

10. The Banking Association of South Africa (BASA). (2014). South African banking sector overview. Retrieved from https://www.banking.org.za/docs/default-source/ publication/banking-sector-overview.pdf

11. Barry, T. A., Lepetit, L., \& Strobel, F. (2016). Bank ownership structure, lending corruption and regulatory environment. Journal of Comparative Economics, 44(3), 732-751. https://doi.org/10.1016/j. jce.2015.08.003

12. Beck, T., De Jonghe, O., \& Schepens, G. (2011). Bank competition and stability: Crosscountry heterogeneity. Journal of Financial Intermediation, 22(2), 218-244. https://doi.org/10.1016/j. jfi.2012.07.001

13. Bikker, J. A., \& Haaf, K. (2002). Measures of Competition and Concentration in the Banking Industry: A Review of Literature.
The Netherlands: Central Bank of the Netherlands.

14. Bitar, M., Naceur, S. B., Ayadi, R., \& Walker, T. (2017). Basel Compliance and Financial Stability: Evidence from Islamic Banks (IMF Working Paper No. 17/161). Retrieved from https:// www.imf.org/en/Publications/ WP/Issues/2017/07/18/BaselCompliance-and-FinancialStability-Evidence-from-IslamicBanks-45040

15. Blair, R. D., \& Heggestad, A. A. (1978). Bank Portfolio and the Probability of Bank Failure. Journal of Money, Credit and Banking, 10(1), 88-93. https://doi org/10.2307/1991474

16. Blanchard, O., Dell'Ariccia, G., \& Mauro, P. (2010). Rethinking macroeconomic policy. Journal of Money, Credit and Banking, 42(1), 199-215. Retrieved from https:// www.imf.org/external/pubs/ft/ spn/2010/spn1003.pdf

17. Boiven, J., Lane, T., \& Meh, C. (2010). Should Monetary policy be used to counteract financial Imbalances? Bank of Canada Review, 23-36. Retrieved from http://www.bankofcanada.ca/ wp-content/uploads/2010/09/ boivin_summer10.pdf

18. Boyd, J. H., \& Runkle, D. R. (1993). Size and performance of banking firms. Journal of Monetary Economics, 31(1), 47-67. https://doi.org/10.1016/03043932(93)90016-9

19. Caprio, G., \& Klingebiel, D. (1996). Bank insolvency: Bad luck, bad policy or bad thinking? Annual World Bank Conference on Development Economics.

20. Caprio, G., \& Levine, R. (2002). Corporate governance in finance: Concepts and international observations (World Bank Paper). Retrieved from http://citeseerx.ist. psu.edu/viewdoc/download?doi=1 0.1.1.19.254\&rep $=$ rep $1 \&$ type $=p d f$

21. Chen, M., Jeon, B. N., Wang, R. \& Wu, J. (2015). Corruption and bank risk-taking: Evidence from emerging economies. Emerging Markets Review, 24, 122-148. https://doi.org/10.1016/j.ememar.2015.05.009
22. Čihák, M. (2007). Systemic loss: A measure of financial stability. Czech Journal of Economics and Finance, 57(1-2), 5-26.

23. De Bandt, O., Camara, B., Pessarossi, P., \& Rose, M. (2017). Can better capitalised banks be more profitable? An analysis of large French banking groups before and after the financial crisis. Economics and Statistics, 494-496, 131-148. https://doi.org/10.24187/ ecostat.2017.494t.1922

24. Demsetz, R. S., Saidenberg, M. R., \& Strahan, P. E. (1996). Banks with something to lose: The disciplinary role of franchise value. Federal Reserve Bank of New York Economic Policy Review, 2, 1-14. Retrieved from https://core.ac.uk/ download/pdf/6792795.pdf

25. Denis, V., \& Negotei, I.-A. (2018). Analysis of Financial Stability: The Construction of a New Composite Financial Stability Index for Euro Area. Ovidius University Annals, Economic Sciences Series, XVIII(1), 264-270.

26. Dexu, H. (2016). China's financial stability. Inherent logic and basic framework. Singapore: World Scientific Publishing Co. Pte. Ltd.

27. Diaconu, I. R., \& Oanea, D. C. (2014). The Main Determinants of Bank's Stability. Evidence from Romanian Banking Sector. Procedia Economics and Finance, 16, 329-335. https://doi.org/10.1016/S22125671(14)00810-7

28. Diaconu, I. R., \& Oanea, D. C. (2015). Determinants of bank profitability: evidence from CreditCoop. Procedia Economics and Finance, 32, 488-495. https://doi.org/10.1016/S22125671(15)01422-7

29. Fiordelisi, F., \& Mare, D. S. (2013). Probability of default and efficiency in cooperative banking. Journal of International Financial Markets, Institutions and Money, 26, 30-45. https://doi. org/10.1016/j.intfin.2013.03.003

30. Fouejieu, A. (2017). Inflation targeting and financial stability in emerging markets. Economic Modelling, 60(C), 51-70. 
31. Gamze, Ö. D. (2018).

Determinants of Bank

Stability: A Financial Statement

Analysis of Turkish Banks.

Sosyoekonomi Journal, 26(38),

87-103. https://doi.org/10.17233/

sosyoekonomi.2018.04.06

32. Gersl, A., \& Hermanek, J. (2006). Financial Stability Indicators: Advantages and Disadvantages of Their Use in the Assessment of the Financial System Stability (Financial Stability Report 2006) (pp. 69-79). Czech National Bank.

33. Giavazzi, F., \& Giovannini, A. (2010). The low-interest-rate trap. Retrieved from http://www.voxeu. org/article/low-interest-rate-trap

34. Goodwin-Groen, R. P. (2006). The National Credit act And Its Regulations in the Context of Access to Finance in South Africa. South Africa: FinMark Trust. Retrieved from http:// www.finmark.org.za/wp-content/ uploads/2016/01/Rep_NCA_AccesstoFinance_2006.pdf

35. Greene, W. H. (2008). Econometric Analysis. New Jersey: PrenticeHall.

36. Greene, W. H. (2012). Econometric Analysis (7th ed). Harlow: Pearson.

37. Hausman, J. A. (1978). Specification tests in econometrics. Econometrica, 46(6), 1251-1271.

38. Havenmann, R., \& Gibson, K. (2014). Financial sector regulation bill 2013: Implementing twin peaks. Retrieved from www.treasury.gov. $\mathrm{za} /$ twinpeaks

39. Ichiue, H., \& Lambert, F. (2016) Post-crisis International Banking; an Analysis with New Regulatory Survey Data (IMF Working Papers No. 16/88). International Monetary Fund.

40. Ikpefan, O. A. (2012). The Impact of Bank Capitalization in the Performance of Nigerian Banking Industry (1986-2006). I-manager's Journal on Management, 6(3), 31-45. https://doi.org/10.26634/ jmgt.6.3.1722

41. Jimenez, G., Lopez, J. A., \& Saurina, J. (2013). How does competition affect bank risktaking? Journal of Financial
Stability, 9, 185-195. https://doi org/10.1016/j.jfs.2013.02.004

42. Keeley, M. C. (1990). Deposit insurance, risk and market power in banking. American Economic Review, 80, 1183-1200.

43. Kibritciogiu, A. (2002). Excessive Risk-taking, Banking Sector Fragility and Banking Crises. (Office of Research Working Paper No. 02-0114). University of Illinois, College of Commerce and Business Administration. Retrieved from https://business. illinois.edu/working_papers/papers/02-0114.pdf

44. Kick, T., \& Prieto, E. (2013) Bank risk taking and competition: evidence from regional banking markets (Discussion Paper Deutsche Bundesbank No. 30/2013). Retrieved from https:// econpapers.repec.org/paper/zbwbubdps/302013.htm

45. Levine, R. (2004). The corporate governance of banks: A concise discussion of concepts and evidence (Policy Research Working Paper No. 3404). https://doi. org/10.1596/1813-9450-3404

46. Marcus, A. J. (1984). Deregulation and bank financial policy. Journal of Banking and Finance, 8, 557-565.

47. Maredza, A., \& Ikhide, S. (2013). The Impact of the Global Financial Crisis on Efficiency and Productivity of the Banking System in South Africa (Working Paper No. 328). Southern Africa: Economic Research.

48. Martinez-Miera, D., \& Repullo, R. (2010). Does competition reduce the risk of bank failure? Review of Financial Studies, 23, 3638-3664.

49. Miah, M. D, \& Uddin, $\mathrm{H}$ (2017). Efficiency and stability: A comparative study between islamic and conventional banks in GCC countries. Future Business Journal, 3(2), 172-185. https://doi. org/10.1016/j.fbj.2017.11.001

50. Miklaszewska, E., Mikołajczyk, K., \& Pawlowska, M. (2012). The consequences of post-crisis regulatory architecture for banks in Central Eastern Europe (NBP Working Paper No. 131). National Bank of Poland, Economic Institute.
51. Mirzaei, A., \& Moore, T. (2014). What are the driving forces of bank competition across different income groups of countries? Journal of International Financial Markets, Institutions and Money, 32, 38-71. https://doi. org/10.1016/j.intfin.2014.05.003

52. Mlambo, K., \& Ncube, M. (2011). Competition and Efficiency in the Banking Sector in South Africa. African Development Review, 23 , 4-15. https://doi.org/10.1111/ j.1467-8268.2010.00268.x

53. Montes, G. C., \& Peixoto, G. B. (2014). Risk-taking channel, bank lending channel and the "paradox of credibility": Evidence from Brazil. Economic Modelling, 39, 82-94.

54. National Treasury. (2018). New Twin Peaks Regulators Established. Retrieved from http://www.treasury.gov.za/twinpeaks

55. OECD. (2011). Bank Competition and Financial Stability. Retrieved from www.banking.org.za

56. Ozili, P. K. (2018). Banking stability determinants in Africa. International Journal of Managerial Finance, 14(4,) 462483. https://doi.org/10.1108/IJMF01-2018-0007

57. Paligorova. T, \& Jimenez, J. (2012). Monetary policy and the risk-taking channel: Insights from the lending behaviour of Banks. Bank of Canada Review, 23-30. Retrieved from http://www. bankofcanada.ca/wp-content/ uploads/2012/11/boc-reviewautumn12-paligorova.pdf

58. Rajan, R. (2006). Has Finance Made the World Riskier? European Financial Management, 12(4), 499-533. https://doi.org/10.1111/j.1468036x.2006.00330.x

59. Reinhardt, F. (1999). Market failure and the environmental policies of firms. Journal of Industrial Ecology, 3(1), 9-21.

60. Roy, A. D. (1952). Safety First and the Holding of Assets. Econometrica, 20(3), 431-449.

61. Schaeck, K., \& Cihak, M. (2010). Competition, efficiency, 
and soundness in banking:

An industrial organization perspective. SSRN Electronic

Journal. https://dx.doi.

org/10.2139/ssrn.1320962

62. Schaeck, K., \& Cihak, M. (2014).

Competition, Efficiency, and

Stability in Banking. Financial Management, 215-241.

63. Schraten, J. (2014). The transformation of the South African credit market. Transformation, 85(1), 1-20. Retrieved from http://transformationjournal.org.za/wp-content/ uploads/2017/04/T85_Part3.pdf

64. Shaddady, A., \& Moore, T. (2018). Investigation of the effects of financial regulation and supervision on bank stability: The application of CAMELS-DEA to quantile regressions. Journal of International Financial Markets, Institutions and Money, 58, 96-116. https://doi.org/10.1016/j.intfin.2018.09.006

65. Shijaku, G. (2017). Bank Stability and Competition: Evidence from Albanian Banking Market. Eurasian Journal of Business and Economics, 10(19), 127154. https://doi.org/10.17015/ ejbe.2017.019.07

66. Srairi, S. (2013). Ownership structure and risk-taking behaviour in conventional and Islamic banks: Evidence for MENA countries. Borsa Istanbul Review, 13, 115-127. Retrieved from http://www.elsevier.com/ journals/borsa-istanbul-review/2214-8450

67. Theobald, S. (2013). The risk of unsecured lending in South Africa (Occasional Research Report). Leriba: Leriba Consulting Limited.

68. Tunay, K. B., \& Yüksel, S. (2017). The relationship between corporate governance and foreign ownership of the banks in developing countries. Contaduríay Administración, 62(5), 1627-1642. https://doi. org/10.1016/j.cya.2017.05.007

69. Vives, X. (2016). Competition and stability in banking: The role of competition policy and regulation. Princeton: Princeton University Press

70. Wagner, W. (2006). Diversification at financial institutions and systemic crises. The Netherlands: Tilburg University, Centre for Economic Research.

71. Wagner, W. (2011). Systemic liquidation risk and the diversitydiversification trade-off. Journal of Finance, LXVI(4), 1141-1176. https://doi.org/10.1111/j.15406261.2011.01666.x
72. Yüksel, S. (2017). Determinants of the credit risk in developing countries after economic crisis: A case of Turkish banking sector In Global financial crisis and its ramifications on capital markets (pp. 401-415). Cham: Springer.

73. Yüksel, S., Mukhtarov, S., Mammadov, E., \& Özsarı, M. (2018). Determinants of Profitability in the Banking Sector: An Analysis of PostSoviet Countries. Economies, 6(3), 41-56. https://doi.org/10.3390/ economies6030041

74. Zhang, Z., Xie, L., Lu, X., \& Zhang, Z. (2015). Determinants of Financial Distress In Large Financial Institutions: Evidence From U.S. Bank Holding Companies. Contemporary Economic Policy: Western Economic Association International, 34(2), 217386. https://doi.org/10.1111/ coep. 12105

75. Zhao, Y. Z. (2017). Effects of Deposit Insurance on SelfDiscipline of Bank Franchise Value. American Journal of Industrial and Business Management, 7, 179-190. https://doi.org/10.4236/ ajibm.2017.73014 